\title{
KEMAMPUAN METAKOGNITIF DAN KOMUNIKASI MATEMATIS DALAM PEMECAHAN MASALAH MATEMATIKA
}

\author{
Sutini \\ UIN Sunan Ampel Surabaya \\ Corresponding Author: sutinimiskun@uinsby.ac.id
}

\begin{abstract}
This descriptive qualitative study aims to describe the metacognitive and communicative abilities of the third-semester students of Mathematics Education of UIN Sunan Ampel Surabaya. Forty students were given a test consists of 2 essay problems of number theory. Three of the answer sheets that each one representing students with high, medium, and low scores were analyzed. Findings show that the students' ability in both aspect are unsatisfactory regardless of their different scores. They are don't show their understanding of the concepts and principles of number theories, some of them still use mathematical terms and notes, and the majority still have the wrong calculation because they not use the complete and correct algorithm. The students' ability in mathematical communication is poor because they can't write the correct mathematical symbols and can't put the mathematical ideas in an acceptable, logical order. They have written the answers that seem to the right answers, but the arrangement of the answers is irrational and jumping, resulting in the answers in low comprehensibility.
\end{abstract}

Keywords: Metacognitive abilities; Communicative abilities; Problem-solving

How to cite: Sutini. (2019). Kemampuan Metakognitif dan Komunikasi Matematis dalam Pemecahan Masalah Matematika. JRPM (Jurnal Review Pembelajaran Matematika), 4(1), 32-47.

\section{PENDAHULUAN}

Menurut Nur (2000), metakognitif berhubungan dengan berpikir mereka sendiri dan kemampuan mereka menggunakan strategi-strategi belajar tertentu dengan tepat. Misalnya, seseorang dengan tipe belajar visual mengetahui bahwa membuat suatu peta konsep merupakan cara terbaik baginya untuk memahami dan mengingat sejumlah besar informasi baru. Metakogitif merupakan salah satu standar kompetensi lulusan yang harus dimiliki oleh siswa. Oleh karena itu, kemampuan metakognitif sebagai salah satu aspek pengetahuan dan tujuan pembelajaran matematika perlu diajarkan dan dilatihkan kepada mahasiswa melalui pelatihan atau pengajaran yang strategis.

Menurut Anderson dan Krathwohl (2001) mengemukakan bahwa strategi kognitif yang sangat penting untuk diajarkan kepada siswa yaitu strategi-strategi kognitif dalam memahami materi matematika, yang meliputi: (1) strategi rehearsal yakni menggaris bawahi dan membuat catatan pinggir, (2) strategi elaborasi yakni membuat ringkasan, dan (3) strategi organisasi yakni membuat peta konsep. Strategi-strategi kognitif dalam pemecahan masalah matematika, yang meliputi: (1) strategi-strategi heuristik, (2) berpikir maju, (3) berpikir mundur, (4) berpikir induktif, dsan (5) berpikir deduktif.

Dalam pembelajaran matematika, seorang siswa yang sudah mempunyai kemampuan 
kemampuan pemahaman matematis dituntut juga untuk bisa mengkomunikasikannya, agar pemahamannya tersebut bisa dimengerti oleh orang lain. Dengan mengkomunikasikan ideide matematisnya kepada orang lain, seorang siswa bisa meningkatkan pemahaman matematisnya. Seperti yang telah dikemukakan oleh Huggins (1999) bahwa untuk meningkatkan pemahaman konseptual matematis, siswa bisa melakukannya dengan mengemukakan ide-ide matematisnya kepada orang lain. Menurut Schoen, Bean dan Ziebarth (dalam Hulukati, 2005) menyatakan bahwa pengertian komunikasi matematis dapat diartikan sebagai kemampuan siswa dalam hal menjelaskan suatu algoritma dan cara unik untuk pemecahan masalah, kemampuan siswa mengkonstruksi dan menjelaskan sajian fenomena dunia nyata secara grafik, kata-kata/kalimat, persamaan, tabel dan sajian secara fisik atau kemampuan siswa memberikan dugaan tentang gambar-gambar geometri.

Metakognisi (metacognition) merupakan suatu istilah yang diperkenalkan oleh Flavell pada tahun 1976. Menurut Flavell dalam Livingstone (1997), metakognisi terdiri dari pengetahuan metakognitif (metacognitive knowledge) dan pengalaman atau regulasi metakognitif (metacognitive experiences or regulation). Pengetahuan metakognitif menunjuk pada diperolehnya pengetahuan tentang proses-proses kognitif, pengetahuan yang dapat dipakai untuk mengontrol proses kognitif. Sedangkan pengalaman metakognitif adalah proses-proses yang dapat diterapkan untuk mengontrol aktivitas-aktivitas kognitif dan mencapai tujuan-tujuan kognitif.

Salah satu keterampilan 4C (Communication, Critical thinking, Communicative, dan Collaborative) dalam kurikulum 2013 revisi 2017 sangat penting dalam meraih kesuksesan dalam dunia yang berkembang sangat cepat dan dinamis adalah komunikasi. Komunikasi juga merupakan salah satu dari empat standar proses NCTM (NCTM, 2000). Oleh karena itu, komunikasi matematis merupakan keterampilan yang perlu dikuasai siswa.

Terkait bentuk-bentuk komunikasi matematika yang harus dimiliki siswa, NCTM (2000) menyatakan bahwa komunikasi matematika dapat dilakukan siswa dalam berbagai bentuk, seperti menyatakan, mengklarifikasi, mengorganisasikan, dan mengkonsolidasi pemikirannya, yang dapat disampaikan melalui lisan, gestur (gerak tubuh), gambar, objek, atau simbol. Dalam prosesnya, ketika siswa mendengarkan penyampaian pemikiran atau pendapat dari temannya, maka siswa akan mengetahui sudut pandang dan strategi temannya terkait masalah yang didiskusikan. Sehingga nantinya siswa akan berusaha memahaminya dan menemukan solusi atau pemikiran yang lain yang menurutnya lebih benar. Ketika menulis dan berdiskusi pun siswa juga akan belajar bagaimana menggunakan bahasa dan 
simbol-simbol matematika dengan benar dan mengungkapkan ide-idenya.

Los Angeles Country Office of Education (LACOE) menyatakan bahwa komunikasi matematika mencakup komunikasi secara lisan maupun tertulis (Mahmudi, 2006). Menurut Mahmudi (2006), komunikasi matematika secara lisan yaitu penyampaian ide-ide matematika dengan mengungkapkannya secara verbal. Misalnya saat siswa menjelaskan alur penyelesaian suatu masalah matematika. Sedangkan komunikasi matematika secara tertulis, dapat dilakukan melalui kata-kata (tertulis), gambar, tabel, dan sebagainya yang menggambarkan ide-ide matematika atau proses berpikir peserta didik.

Pada NCTM (2000), masalah matematika selalu dinyatakan dalam bentuk pertanyaan atau soal. Meskipun demikian, tidak semua pertanyaan atau soal dapat dikatakan sebagai masalah. Sebuah pertanyaan atau soal tertentu dapat menjadi masalah bagi seseorang, namun belum tentu menjadi masalah bagi orang lain. Rofiqoh (2015) mendefinisikan masalah matematika adalah suatu situasi yang terhalang dikarenakan kurangnya informasi tentang algoritma yang dapat digunakan untuk menyelesaikan masalah tersebut. Hal ini berarti bahwa, suatu pertanyaan atau soal tertentu dapat dikatakan sebagai masalah matematika jika belum diketahui secara langsung algoritma yang dapat digunakan untuk menyelesaikan masalah tersebut.

Tahapan pemecahan masalah Polya (1973) yang digunakan dalam penelitian ini yaitu: memahami masalah, menyusun rencana, menyelesaikan masalah sesuai rencana, dan memeriksa kembali jawaban yang telah diperoleh dengan benar. Berdasarkan uraian tahapan pemecahan masalah Polya maka disusun indikator pemecahan masalah tahapan Polya. Pertama, indikator memahami masalah yaitu: (1) mahasiswa dapat menentukan hal yang diketahui dari soal, (2) mahasiswa dapat menentukan hal yang ditanyakan dari soal. Kedua, indikator menyusun rencana yaitu: (1) mahasiswa dapat menentukan syarat lain yang tidak diketahui pada soal seperti rumus atau informasi lainnya jika memang ada, (2) mahasiswa dapat mengunakan semua informasi yang ada pada soal, (3) mahasiswa dapat membuat rencana atau langkah-langkah penyelesaian dari soal yang diberikan. Ketiga, indikator menyelesaikan masalah sesuai rencana yaitu: (1) mahasiswa dapat menyelesaikan soal yang ada sesuai dengan langkah-langkah yang telah dibuat awal, (2) mahasiswa dapat menjawab soal dengan tepat. Keempat, indikator memeriksa kembali jawaban yang telah diperoleh dengan benar yaitu: (1) mahasiswa dapat memeriksa kembali jawaban yang telah diperoleh dengan menggunakan langkah yang benar, (2) mahasiswa dapat menyakini kebenaran dari jawaban yang telah. 
Indikator metakognitif dalam pemecahan masalah matematika yaitu terdiri dari pengetahuan matematika dan pengetahuan strategik. Adapun indikator pengetahuan matematika meliputi: menunjukkan pemahaman konsep dan prinsip yang lengkap dari masalah matematika, menggunakan istilah dan notasi matematika yang sesuai, dan menggunakan algoritma yang lengkap dan tepat. Sedangkan indikator dari pengetahuan strategik meliputi mengidentifikasi semua unsur-unsur penting dari masalah dan menunjukkan pemahaman yang lengkap tentang hubungan antar unsur-unsur, mencerminkan penggunaan strategi yang tepat dan sistematis untuk memecahkan masalah, dan secara meyakinkan menunjukkan proses pemecahan yang sistematis dan lengkap (Sutini, 2017).

Dalam penelitian ini, untuk mengetahui kemampuan komunikasi matematis mahasiswa secara tulis dan lisan dalam pemecahan masalah adalah melalui lima indikator yaitu menuliskan jawaban dengan simbol matematika yang tepat, menyusun jawaban secara terurut dan logis, memulai menulis jawaban mengarah pada pertanyaan, memberikan jawaban dengan benar, serta menyusun kalimat yang mudah dipahami.

\section{METODE PENELITIAN}

Jenis penelitian ini adalah deskriptif karena data yang dihasilkan berbentuk verbal dan bertujuan untuk mendeskripsikan kemampuan metakognitif dan komunikasi matematis mahasiswa dalam pemecahan masalah pada matakuliah teori bilangan.

Menurut Ningsih (2012), Adapun penetapan subjek penelitian berdasarkan teknik purpose sampling dengan memilih 3 mahasiswa yaitu satu mahasiswa dari kelompok tinggi, satu mahasiswa dari kelompok sedang, dan satu mahasiswa dari kelompok rendah. Pengambilan subjek penelitian pada setiap kelompok dipilih berdasarkan skor yang diperoleh dan kemampuan metakognitif dan komunikasi mahasiswa dalam mengemukakan ide-ide atau pemikiranya yang tertuang dalam jawaban tes. Ketiga mahasiswa yang telah ditetapkan sebagai subjek penelitian dari kelompok tinggi (S1), kelompok sedang (S2), dan kelompok rendah (S3).

Prosedur pengumpulan data yaitu menggunakan tes tulis, observasi, dan wawancara. Observasi dilakukan sebelum penelitian dilaksanakan. Hasil tes diperiksa dan diberi skor berdasarkan rubrik penskoran tes. Skor tes digunakan untuk memilih subjek penelitian dan juga sebagai pertimbangan wawancara, serta analisis penelitian. Selanjutnya, peneliti juga memperhatikan jawaban mahasiswa dalam wawancara sehingga perlu adanya perpaduan 
antara instrumen wawancara yang telah dibuat dengan jawaban dari subjek penelitian. Subjek yang diwawancarai ada tiga dan diwawancarai secara bergantian.

\section{HASIL DAN PEMBAHASAN}

Berdasarkan hasil tes kemampuan metakognitif dan komunikasi matematis, peneliti memilih 3 siswa dari 40 siswa yang telah diberi tes berdasarkan skor dalam menyelesaikan masalah. Ketiga siswa tersebut adalah $\mathrm{S}_{1}, \mathrm{~S}_{2}$, dan $\mathrm{S}_{3}$. Paparannya sebagai berikut:

\section{Kemampuan Metakognitif dalam Pemecahan Masalah}

Subjek $\mathrm{S}_{1}$ menunjukkan pemahaman konsep dan prinsip yang kurang lengkap dari masalah matematika, menggunakan istilah dan notasi matematika yang kurang sesuai, menggunakan algoritma yang belum lengkap dan tepat. Berikut temuan-temuan berdasarkan jawaban tertulis $\mathrm{S}_{1} . \mathrm{S}_{1}$ tidak konsisten dalam memeriksa bagian-bagian $x$ yang memenuhi untuk $r(x)=\llbracket x \rrbracket$. Tertulis di dalam penjelasan bahwa nilai $x$ pada $0<x \leq 4$ dipecah atas $1<x \leq 2,2<x \leq 3$, dan $3<x \leq 4$, sedangkan $0<x \leq 1$ tidak dianggap bagian dari $0<x \leq 4$. $\mathrm{S}_{1}$ membuat grafik $y=\llbracket x \rrbracket$ hanya berdasarkan ingatannya saja, bukan berdasarkan definisi dari $\llbracket x \rrbracket . S_{1}$ tidak memeriksa kembali apakah jawabannya logis atau tidak. Oleh karena itu walaupun grafik $y=-x-2$ berupa segmen garis naik atau $y=-(x+2)^{2}+1$ berupa bagian parabola yang terbuka ke atas, $\mathrm{S}_{1}$ merasa aman saja. $\mathrm{S}_{1}$ menganggap grafik $y=g(x)=-|f(x)|$ sebagaimana grafik $=-f(x)$. Hal ini berdasarkan jawaban $S_{1}$ yang menyatakan bahwa terdapat tiga domain dan tiga range.

Subjek $\mathrm{S}_{2}$ menunjukkan pemahaman konsep dan prinsip yang tidak lengkap dari masalah matematika, menggunakan istilah dan notasi matematika yang tidak sesuai, menggunakan algoritma yang belum lengkap dan tepat. $\mathrm{S}_{2}$ tidak memahami arti domain suatu fungsi seperti tampak dari jawaban tentang domain dari $y=r(x)=-x-1$, untuk $-5\left\langle x<-3\right.$ adalah $(-\infty, \infty)$. $\mathrm{S}_{2}$ belum dapat menggambar grafik dari domain yang diberikan seperti tampak pada menggambar grafik untuk $y=r(x)=-x-1$, untuk $-5\left\langle x<-3, \mathrm{~S}_{2}\right.$ menggambar garis yang melalui titik $(-3,2)$ dan $(-4,3)$ kemudian memperpanjang kekiri dan kekanan. Begitu pula untuk $y=r(x)=-(x+2)^{2}+1$, untuk $-2 \leq x \leq 1, \mathrm{~S}_{2}$ menggambar garisnya diperpanjang hingga $x$ nya melebihi -3 dan $x$ nya melebihi $1 . S_{2}$ tidak memahami arti inteval suatu bilangan, seperti tampak dari $y=r(x)=-x-1$, untuk $-5\left\langle x\left\langle-2, \mathrm{~S}_{2}\right.\right.$ memilih hanya dua titik yang memenuhi 
yaitu -3 dan -4 ". $S_{2}$ tidak memahami pengertian fungsi bersyarat karena dari soal nomor 1 grafiknya digambar sendiri-sendiri. $S_{2}$ menjawab pertanyaan nomor 2 hanya berupa gambar tanpa diberikan penjelasan apapun.

Subjek $\mathrm{S}_{3}$ enggan menulis ulang kondisi-kondisi dari masing-masing persamaan. $\mathrm{S}_{3}$ tidak memikirkan untuk memberikan penjelasan tentang pembuatan grafik segmen garis cukup dengan mencari dua titik sampel. Demikian juga tidak terpikir oleh $\mathrm{S}_{3}$ tentang penulisan identifikasi parabola yang nantinya dapat digunakan untuk memeriksa ulang jawabannya. Terdapat dua kemungkinan kesan terhadap latar belakang mengapa $S_{3}$ tidak menuliskan penjelasan terhadap grafik $y=\llbracket x \rrbracket$. Pertama, $S_{3}$ beranggapan bahwa jika kita sudah tahu bentuk grafik dari $y=\llbracket x \rrbracket$, maka kita tidak perlu memberi penjelasan. Kedua, $\mathrm{S}_{3}$ memang tidak bisa menjelaskan mengapa grafik $y=\llbracket x \rrbracket$ sebagaimana yang telah di gambarkan. Hal ini dikemukakan dengan asumsi bahwa penulisan simbol $\wedge$ dia maksudkan sebagai irisan himpunan. $S_{3}$ mengabaikan pentingnya menuliskan simbol \{\} untuk menyatakan himpunan yang dia maksud. $\mathrm{S}_{3}$ hanya menuliskan angka 4 untuk menyatakan $\{4\} . S_{3}$ kurang teliti dalam membaca soal nomor $2 . S_{3}$ memberi penjelasan yang terkait hubungan antara fungsi $f(x)$ dan $g(x)$ sebagai $g(x)=-f(x)$ sedangkan hal yang diketahui oleh soal adalah $g(x)=-|f(x)|$. Kesalahan ini berdampak terhadap grafik dan jawaban yang ia buat. $\mathrm{S}_{3}$ membuat grafik $y=g(x)$ yang berimpit dengan grafik $y=$ $-f(x)$ dan grafik $y=f(x)$ berimpit dengan grafik $=-g(x)$. Oleh karena itu jawaban $\mathrm{S}_{3}$ adalah $f(x)=-g(x)$ padahal soal menanyakan apakah $f(x)=-|g(x)|$. Berdasarkan paparan data, $\mathrm{S}_{3}$ menunjukkan pemahaman konsep dan prinsip yang tidak lengkap dari masalah matematika, menggunakan istilah dan notasi matematika yang tidak sesuai, menggunakan algoritma yang belum lengkap dan tepat.

\section{Komunikasi Matematis dalam Memecahkan Masalah Matematika}

Subjek $S_{1}$ menuliskan pendapatnya dengan urut, dia memulai proses mencari jawabannya dengan hal yang sudah mengarah pada jawaban akhir. Walaupun demikian, $\mathrm{S}_{1}$ melakukan hal-hal yang kurang logis. Temuan berdasarkan jawaban tertulis $\mathrm{S}_{1}$ yaitu dalam mencari titik-titik sampel untuk membuat grafik fungsi linier pada interval buka, $\mathrm{S}_{1}$ tidak memeriksa titik-titik ujung interval, yaitu 5. $S_{1}$ memeriksa titik-titik yang dekat dengan titik ujung, yaitu 4,5. $\mathrm{S}_{1}$ tidak konsisten dalam memeriksa bagian-bagian $x$ yang memenuhi untuk $r(x)=\llbracket x \rrbracket$. Tertulis di dalam penjelasan bahwa nilai $x$ pada $0<x \leq 4$ dipecah atas $1<$ $x \leq 2,2<x \leq 3$, dan $3<x \leq 4$, sedangkan $0<x \leq 1$ tidak dianggap bagian dari $0<$ 
$x \leq 4 . S_{1}$ membuat grafik $y=\llbracket x \rrbracket$ hanya berdasarkan ingatannya saja, bukan berdasarkan definisi dari $\llbracket x \rrbracket$. Hal ini berdasarkan jawaban $S_{1}$ yang menyatakan bahwa terdapat tiga domain dan tiga range. $\mathrm{S}_{1}$ menganggap grafik $y=g(x)=-|f(x)|$ sebagaimana grafik $=$ $-f(x)$. Hal ini tampak dengan dibuatnya grafik yang diperoleh dengan mencerminkan grafik $y=f(x)$ terhadap sumbu $x$.

Subjek $\mathrm{S}_{1}$ dapat mengomunikasikan pendapatnya dengan lancar, urut dan bahasa yang mudah dimengerti, walaupun ditemukan beberapa hal yang tidak logis. Hal-hal berikut merupakan temuan yang diperoleh berdasarkan wawancara dengan $S_{1} . S_{1}$ berpendapat agar grafik yang dibuat lebih akurat, maka semakin lebar interval untuk $x$, maka sebaiknya semakin banyak titik sampel yang dihitung. $\mathrm{S}_{1}$ tidak konsisten dalam memeriksa bagianbagian $x$ yang memenuhi untuk $r(x)=\llbracket x \rrbracket$. $S_{1}$ menyatakan bahwa nilai $x$ pada $0<x \leq 4$ dipecah atas $1<x \leq 2,2<x \leq 3$, dan $3<x \leq 4$, sedangkan $0<x \leq 1$ tidak dianggap bagian dari $0<x \leq 4$ karena pada $0<x \leq 4,0$ tidak ikut. $S_{1}$ membuat grafik $y=\llbracket x \rrbracket$ hanya berdasarkan ingatannya saja, bukan berdasarkan definisi dari $\llbracket x \rrbracket . S_{1}$ tidak memeriksa kembali apakah jawabannya logis atau tidak. $\mathrm{S}_{1}$ tidak mengaitkan grafik yang dibuat dengan teori yang melandasinya. Oleh karena itu, ketika terjadi salah hitung yang mengakibatkan grafik $y=-x-2$ berupa segmen garis naik atau $y=-(x+2)^{2}+1$ berupa bagian parabola yang terbuka ke atas, $S_{1}$ merasa aman saja. $S_{1}$ tidak konsisten dalam menganggap domain dan range suatu fungsi harus tunggal. $\mathrm{S}_{1}$ menganggap grafik $y=$ $g(x)=-|f(x)|$ sebagaimana grafik $y=-f(x)$ karena waktunya tidak mencukupi. Secara grafis, $\mathrm{S}_{1}$ memandang bahwa grafik fungsi nilai mutlak $y=|x|$ yang bagian kiri merupakan hasil pencerminan terhadap sumbu $x$ dari grafik $y=|x|$ yang bagian kanan, yaitu grafik $y=x$. Adapun hasil pekerjaan siswa $S_{1}$ disajikan pada Gambar 1 berikut:

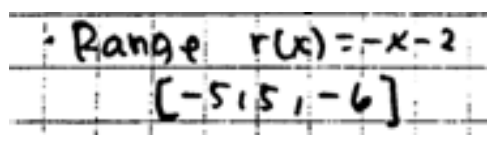

Gambar 1. Jawaban $\mathrm{S}_{1}$ Soal $1 \mathrm{~b}$ tentang Range $r(x)$.

Subjek $\mathrm{S}_{2}$ dalam menuliskan pendapatnya sudah urut. $\mathrm{S}_{2}$ memulai proses mencari jawabannya dengan hal yang sudah mengarah pada jawaban akhir. Walaupun demikian, $\mathrm{S}_{2}$ melakukan hal-hal yang kurang logis. Berikut temuan-temuan berdasarkan jawaban tertulis $\mathrm{S}_{2}$. $\mathrm{S}_{2}$ tidak memahami arti domain suatu fungsi seperti tampak dari jawaban tentang domain dari $y=r(x)=-x-1$, untuk $-5<x<-3$ adalah $\quad(-\infty, \infty) . \quad \mathrm{S}_{2}$ belum dapat menggambar grafik dari domain yang diberikan seperti tampak pada menggambar grafik 
untuk $y=r(x)=-x-1$, untuk $-5\left\langle x<-3, \mathrm{~S}_{2}\right.$ menggambar garis yang melalui titik $(-3,2)$ dan $(-4,3)$ kemudian memperpanjang ke kiri dan ke kanan. Begitu pula untuk $y=r(x)=-(x+2)^{2}+1$, untuk $-2 \leq x \leq 1 \quad \mathrm{~S}_{2}$ menggambar garisnya diperpanjang hingga $x$ nya melebihi -3 dan $x$ nya melebihi $1 . S_{2}$ tidak memahami pengertian fungsi bersyarat karena dari soal nomor 1 grafiknya digambar sendiri-sendiri. $\mathrm{S}_{2}$ menjawab pertanyaan nomor 2 hanya berupa gambar tanpa diberikan penjelasan apapun.

Subjek $\mathrm{S}_{2}$ dapat mengomunikasikan pendapatnya dengan lancar, urut, dan dengan bahasa yang mudah dimengerti, walaupun ditemukan beberapa hal yang tidak logis. Hal-hal berikut merupakan temuan yang diperoleh berdasarkan wawancara dengan $S_{2}$. $S_{2}$ tidak memahami arti domain suatu fungsi seperti tampak dari pertanyaan "domainnya bagaimana? $x$ itu domain apa bukan? ", jawaban $\mathrm{S}_{2}$ yaitu "domain dari $y=r(x)=-x-1$, untuk $-5\left\langle x<-3\right.$ adalah $(-\infty, \infty)$ ". $\mathrm{S}_{2}$ belum dapat menggambar grafik dari domain yang diberikan seperti tampak pada menggambar grafik untuk $y=r(x)=-x-1$, untuk $-5\langle x<-3$, "digambar garis yang melalui titik $(-3,2)$ dan $(-4,3)$ terus jadinya seperti ini dan diperpanjang ke kiri dan ke kanan". $S_{2}$ tidak memahami pengertian fungsi bilangan bulat terbesar tampak dari ketika ditanya untuk $r=[|x|]$, untuk $1\langle x \leq 4$ apakah fungsi bilangan bulat terbesar? Kenapa grafiknya garis $\mathrm{y}=$ 4?, $\mathrm{S}_{2}$ menjawab karena diambil bilangan bulat terbesar pada interval $1<x \leq 4$ adalah 4 sehingga gambarnya adalah garis lurus yang sejajar sumbu-x melalui titik $(0,4)$. $\mathrm{S}_{2}$ tidak memahami pengertian fungsi bersyarat karena dari soal nomor 1 grafiknya digambar sendiri-sendiri, hal ini tampak dari wawancara "P: Ada berapa fungsi yang disuruh menggambar?", "S $\mathrm{S}_{2}$ : Satu fungsi pak", "P: Yang anda gambar?”, " $\mathrm{S}_{2}$ : Sendiri-sendiri pak, mestinya dijadikan satu ya pak". $S_{2}$ menjawab pertanyaan nomor 2 dengan cara dicoba-coba tanpa landasan konsep yang jelas, pada jawabannya pun hanya ada gambar dan ketika ditanya untuk menjelaskan gambar jawaban $\mathrm{S}_{2}$ tidak jelas seperti wawancara " $\mathrm{S}_{2}$ : Lupa pak, saya coba hasilnya digeser pak”, “ P: Apa ini bukan jawaban? Karena jawabannya sama atau tidak, jika $g(x)=-|f(x)|$ apakah $f(x)=-|g(x)|$ ?", "S: Tidak pak", "P: Jika tidak sama apa bedanya? Apa karena digeser? Apa yang mempengaruhi anda sehingga diperoleh hasil yang menggeser", "S$S_{2}$ : Kemarin saya coba-coba bikin trus hasilnya digeser". Adapun hasil pekerjaan siswa $S_{2}$ disajikan pada Gambar 2 berikut: 


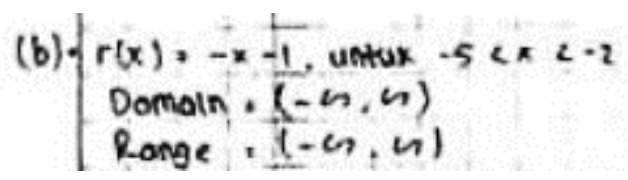

Gambar 2. Jawaban $\mathrm{S}_{2}$ Soal 1b. tentang Domain dan Range r(x).

Berdasarkan paparan data maka ditemukan komunikasi matematis tulis $\mathrm{S}_{3}$, subjek $\mathrm{S}_{3}$ enggan menulis ulang kondisi-kondisi dari masing-masing persamaan. Keengganan ini dapat berdampak kurang baik terhadap siswanya kelak. $S_{3}$ tentang penulisan identifikasi parabola yang nantinya dapat digunakan untuk memeriksa ulang jawabannya. Terdapat dua kemungkinan kesan terhadap latar belakang mengapa $S_{3}$ tidak menuliskan penjelasan terhadap grafik $y=\llbracket x \rrbracket$. Pertama, $\mathrm{S}_{3}$ beranggapan bahwa jika kita sudah tahu bentuk grafik dari $y=\llbracket x \rrbracket$, maka kita tidak perlu memberi penjelasan. Kedua, $\mathrm{S}_{3}$ memang tidak bisa menjelaskan mengapa grafik $y=\llbracket x \rrbracket$ sebagaimana yang telah di gambarkan. $\mathrm{S}_{3}$ terbiasa tidak menuliskan simbol "="untuk menyatakan dua hal matematis yang sama. $\mathrm{S}_{3}$ masih belum bisa membedakan antara simbol konektif antar pernyataan dengan simbol relasi pada himpunan. $S_{3}$ masih belum bisa menerapkan dengan tepat antara pengertian gabungan dan irisan. Hal ini dikemukakan dengan asumsi bahwa penulisan simbol " $N$ " dia maksudkan sebagai irisan himpunan. $S_{3}$ mengabaikan pentingnya menuliskan simbol \{\} untuk menyatakan himpunan yang dia maksud. $S_{3}$ hanya menuliskan angka 4 untuk menyatakan $\{4\} . S_{3}$ kurang teliti dalam membaca soal nomor $2 . S_{3}$ memberi penjelasan yang terkait hubungan antara fungsi $f(x)$ dan $g(x)$ sebagai $g(x)=-f(x)$ sedangkan hal yang diketahui oleh soal adalah $g(x)=-|f(x)|$. Kesalahan ini berdampak terhadap grafik dan jawaban yang ia buat. $\mathrm{S}_{3}$ membuat grafik $y=g(x)$ yang berimpit dengan grafik $y=$ $-f(x)$ dan grafik $y=f(x)$ berimpit dengan grafik $=-g(x)$. Oleh karena itu jawaban $\mathrm{S}_{3}$ adalah $f(x)=-g(x)$ padahal soal menanyakan apakah $f(x)=-|g(x)|$

Adapun analisis data komunikasi lisan dan tulis dalam penelitian ini disajikan sebagai berikut:

\section{Memahami konsep dan prinsip}

Paparan data terlihat bahwa $S_{1}$ hanya sebagian memahami konsep dan prinsip hal ini ditunjukkan bahwa $\mathrm{S}_{1}$ tidak menuliskan simbol yang menyatakan definisi domain dan range. Pada saat pengisian tabel, $\mathrm{S}_{1}$ menuliskan kolom $f(x)$ padahal seharusnya $r(x)$ dan pengisian nilai fungsinya tidak sesuai dengan rumus fungsi $r(x)$. Pada saat memberikan penjelasan $r(x)=\llbracket x \rrbracket$ untuk $0<x \leq 4, \mathrm{~S}_{1}$ hanya menuliskan interval-interval $1<x \leq 2$, $2<x \leq 3$, dan $3<x \leq 4$ tanpa menuliskan nilai fungsi yang terkait. Kemudian hal yang 
dilakukan $\mathrm{S}_{2}$ tiba-tiba menuliskan $y=4$ tanpa memberi penjelasan $y=\llbracket x \rrbracket$ pada selang $0<x \leq 4$. Tanpa memberi penjelasan fungsi itu apa. Selanjutnya juga yang dilakukan $\mathrm{S}_{3}$ yaitu membuat grafik $y=\llbracket x \rrbracket$ pada selang $0<x \leq 4$ dengan benar tetapi tidak ada penjelasan secara aljabar. Bahkan $S_{1}, S_{2}$, dan $S_{3}$ pada soal nomor 2 tidak memahami konsep sama sekali sehingga pada jawaban Tidak mengarah pada tertanyaan, karena yang diolah adalah hubungan antara $g(x)=-f(x)$ bukan $g(x)=-|f(x)|$. Jawaban salah, karena yang diolah salah, yaitu $g(x)=-f(x)$ padahal seharusnya $g(x)=-|f(x)|$.

\section{Menggunakan istilah dan notasi matematika yang sesuai}

Paparan data di atas menunjukkan bahwa $\mathrm{S}_{1}, \mathrm{~S}_{2}$, dan $\mathrm{S}_{3}$ sebagian menggunakan istilah dan notasi matematika. Hal itu ditunjukkan berdasarkan gambar 1, tampak adanya istilah dan notasi yang tidak sesuai dalam membuat grafik $y=\llbracket x \rrbracket$ untuk $0<x \leq 4$, domain dan range ditentukan tanpa proses memperolehnya, dalam satu fungsi terdapat tiga domain dan tiga range. Kemudian $\mathrm{S}_{2}$ tidak menguraikan $\llbracket x \rrbracket$ pada interval $1<x \leq 4$, sehingga simbol-simbol matematika yang diperlukan tidak ditulis. Sedangkan pada soal nomor 2, grafik yang digambar tanpa penjelasan atau notasi yang menunjukkan fungsi sehingga sehingga tidak menuliskan simbol yang menyatakan definisi $|f(x)|$ dan $|g(x)|$.

\section{Menggunakan algoritma yang lengkap dan tepat}

Paparan data terlihat bahwa $S_{1}, S_{2}$, dan $S_{3}$ sebagian besar perhitungan salah karena dalam menggunakan algoritma tidak lengkap dan tidak tepat. Hal itu ditunjukkan $\mathrm{S}_{1}$ melakukan kesalahan dalam mengisi tabel untuk menentukan titik-titik sampel, $\mathrm{S}_{1}$ melakukan kesalahan dalam menjelasan $r(x)=\llbracket x \rrbracket$ untuk $0<x \leq 4$, Grafik yang dibuat oleh $\mathrm{S}_{1}$ salah. Kesalahan yang dilakukan adalah menggambarkan grafik $y=-x-2$ sebagai segmen garis naik, $y=-(x+2)^{2}+1$ sebagai bagian parabola yang terbuka ke atas, dan $y=\llbracket x \rrbracket$ dengan ujung terbuka dan tertutup terbalik serta tidak menggambar $y=$ $\llbracket x \rrbracket$ pada interval $[0,1)$. Selanjutnya $S_{1}$ pada soal nomor 2 yaitu tidak menjawab, hanya membuat grafik tanpa penjelasan sehingga dapat dikatakan bahwa penulisan jawaban tidak mengarah pada pertanyaan. Terdapat lompatan proses pengerjaan karena $\mathrm{S}_{2}$ tidak menuliskan penjelasan secara aljabar yang mengarah pada grafik yang dibuat, $\mathrm{S}_{2}$ membuat grafik yang dinamakan $f(x)=-|g(x)|$ dengan menggeser grafik $y=f(x)$ yang diberikan oleh soal ke kiri. Oleh karena itu terdapat dua hal yang tidak logis di sini. Pertama, menuliskan persamaan grafik fungsi sebagai $f(x)=-|g(x)|$ dan ke dua, melakukan prinsip translasi pada grafik fungsi yang hubungannya berupa nilai mutlak. 
Penulisan jawaban sudah mengarah pada pertanyaan, tetapi banyak lompatan. berdasarkan pekerjaan $\mathrm{S}_{3}$ yang tampak pada gambar 6 terlihat bahwa grafik yang dibuat sudah benar, akan tetapi penjelasan yang diberikan masih belum rinci dan bahkan ada yang masih belum tepat Hal-hal berikut menunjukkan bahwa $S_{3}$ masih belum lengkap dan kurang tepat dalam menuliskan simbol-simbol matematika. $\mathrm{S}_{3}$ tidak menuliskan kondisi-kondisi $x$ yang memenuhi persamaan $y=-x-2, \quad y=-(x+2)^{2}-1$, dan $y=\llbracket x \rrbracket . \mathrm{S}_{3}$ memulai jawaban dengan mengolah informasi $r(x)=-x-2, \quad r(x)=-(x+2)^{2}-1 . \mathrm{S}_{3}$ menuliskan informasi $r(x)=\llbracket x \rrbracket$ tanpa mengolahnya. Oleh karena itu, dapat dikatakan bahwa penulisan jawaban sudah mengarah pada pertanyaan, walaupun ada lompatan.

Berdasarkan analisis data, dapat dibahas beberapa hal sebagai berikut:

\section{Menuliskan Jawaban dengan Simbol Matematika yang Tepat}

Menuliskan jawaban dengan simbol yang tepat diperlukan agar orang lain bisa memahami apa yang dituliskan dengan tepat pula. Hal ini sesuai dengan yang disebutkan dalam NCTM (2000) bahwa salah satu standar komunikasi adalah menggunakan bahasa matematika untuk menyatakan ide-ide matematika secara benar. Penulisan simbol dengan tepat juga diperlukan untuk mempermudah pengorganisasian pemikiran agar diperoleh langkah-langkah yang tepat dalam menyusun jawaban.

Dari paparan data terlihat bahwa dalam menentukan domain dan range, subjek tidak menuliskan simbol yang menyatakan definisi domain dan range. Hal ini menunjukkan kekurang telitian dari subjek dalam penulisan simbol matematika agar bisa dipahami oleh orang lain. Dalam NCTM (2000) juga disebutkan bahwa komunikasi merupakan cara untuk mengungkapkan ide dan mengklarifikasi pemahamannya. Subjek tidak menuliskan simbol matematikanya maka orang lain tidak bisa memahami apa yang dipahami dengan benar. Namun demikian terlihat bahwa salah satu subjek sudah memberikan jawaban yang benar untuk domain yang ditanyakan. Hal ini menunjukkan bahwa pemahaman subjek tersebut sudah tepat mengenai domain dari fungsi yang diberikan, walaupun dalam menuliskan simbol matematika kurang lengkap.

\section{Keterurutan dan kelogisan dalam menyusun jawaban}

Keterurutan dan kelogisan dalam mengungkapkan ide matematika diperlukan agar orang lain bisa menerima ide tersebut secara runtut dan benar. Sebagaimana disebutkan dalam NCTM (2000) bahwa agar hasil-hasil pemikiran matematika bisa dikenali dengan benar, bukti-bukti yang diberikan harus bisa diterima oleh komunitas matematika. Salah satu syarat agar diterima di komunitas matematika, hal-hal yang diungkapkan harus bersifat 
logis. Terdapat salah satu subjek dalam menyusun jawabannya tidak logis, walaupun cenderung terurut. Contohnya adalah grafik $y=-x-2$ digambarkan sebagai segmen garis naik, padahal seharusnya turun karena gradiennya negatif. Begitu juga saat menggambarkan $\mathrm{y}=-(\mathrm{x}+2)^{2}+1$ berupa bagian parabola yang terbuka ke atas, padahal seharusnya terbuka ke bawah. Ketidaklogisan jawaban subjek ini salah satunya diakibatkan oleh kesalahan saat mensubstitusikan nilai $x$ ke dalam fungsi $r(x)$. Kesalahan ini, selain mengakibatkan kesalahan dalam menentukan domain dan range $r(x)$, juga mengakibatkan kesalahan dalam menggambarkan grafik.

Ketidaklogisan dan ketidak-runtutan lain dari subjek tersebut dalam mengerjakan tugas adalah saat menjawab pertanyaan $1 \mathrm{~b}$. yang menanyakan domain dan range dari fungsi $r(x)$. Subjek tanpa memberikan urutan jawaban, langsung menjawab dalam satu fungsi terdapat tiga domain dan tiga range. Jawaban subjek ini tidak logis karena tidak mungkin dalam satu fungsi terdapat tiga domain dan tiga range yang berbeda. Sedangkan terdapat subjek lain yang sudah terlihat urut dalam menentukan domain dan range ini, namun karena ia tidak memahami maksud domain dan range maka jawaban yang diberikan tidak logis dan berakibat pada kesalahan. Sedangkan untuk subjek terakhir, walaupun sudah membuat grafik $y=\llbracket x \rrbracket$ pada selang $0<x \leq 4$ dengan benar tetapi terdapat lompatan karena tidak ada penjelasan secara aljabar serta tidak ada penjelasan mengapa grafiknya berbentuk segmen-segmen seperti tangga. Hal ini dimungkinkan karena subjek tersebut sudah merasa cukup dengan jawaban tersebut dan kurang terbiasa mengkomunikasikan jawaban secara lengkap kepada orang lain.

\section{Penulisan jawaban yang mengarah sesuai pertanyaan}

Jawaban yang mengarah sesuai pertanyaan diperlukan agar jawaban yang diberikan sesuai dengan yang ditanyakan. Dalam hal ini diperlukan pengorganisasian pemikiran agar bisa memberikan jawaban yang sesuai. Hal tersebut seperti dinyatakan dalam NCTM (2000) bahwa salah satu aspek dalam standar proses komunikasi adalah mengorganisasi dan mengkonsolidasi pemikiran matematika melalui komunikasi. Jika penulisan jawaban tidak mengarah sesuai pertanyaan maka akan mempersulit langkah-langkah berikutnya. Hal ini akan berakibat pada jawaban yang tidak benar atau tidak ditemukannya jawaban akhir.

Pada paparan salah satu subjek pada soal nomor 1, pada saat akan membuat grafik fungsi $y=r(x)$, subjek mengawali jawaban dengan memilahnya atas tiga bagian sub interval. Hal ini sudah mengarah pada jawaban yang tepat sesuai pertanyaan. Tetapi subjek tidak menuliskan domain dan range di awal pencariannya, hal ini akan berakibat pada 
kesalahan berikutnya. Oleh karena itu jawabannya jauh dari pertanyaan. Sedangkan untuk subjek lain pada soal nomor 1 dapat dikatakan bahwa penulisan jawaban sudah mengarah pada pertanyaan, walaupun ada lompatan, sedangkan untuk nomor 2 tidak mengarah pada pertanyaan. Dari kasus tersebut dapat diketahui bahwa memulai menulis jawaban dengan benar diperlukan untuk proses penyelesaian masalah berikutnya. Sehingga aspek menulis jawaban dengan benar ini menjadi sangat penting, sebagaimana diungkapkan Pugalee (2001) agar siswa bisa terlatih kemampuan komunikasi matematisnya, maka dalam pembelajaran siswa perlu dibiasakan untuk memberikan argumen atas setiap jawabannya serta memberikan tanggapan atas jawaban yang diberikan oleh orang lain, sehingga apa yang sedang dipelajari menjadi lebih bermakna baginya. Hal ini karena dengan menulis secara benar akan membantu pemahaman pada konsep selanjutnya.

\section{Kebenaran jawaban yang diberikan}

Saat menentukan range soal $1 \mathrm{~b}$ dari $r(x)$ oleh semua subjek, selain mereka menuliskan simbol yang kurang tepat, jawaban akhir yang diberikan juga salah. Kesalahan untuk ini berawal saat salah dalam mensubstitusikan nilai x pada fungsi $r(x)$. untuk $\mathrm{x}=-4$, perhitungan yang dihasilkan $r(x)=-6$ (salah), sedangkan untuk $\mathrm{x}=-3,5$ perhitungan yang dihasilkan $\mathrm{r}(\mathrm{x})=-5,5$. Dalam hal mengklarifikasi pemahaman sebagaimana disebutkan dalam NCTM (2000).

Pada bagian lain NCTM (2000) dinyatakan bahwa menulis dalam matematika akan membantu mengkonsolidasi pemikirannya, hal ini karena tulisannya bisa digunakan untuk merefleksikan pekerjaanya dan mengklarifikasi pemikiran yang telah dikembangkan. Dalam hal ini subjek tidak melakukan klarifikasi dan refleksi terhadap pekerjaannya yang pertama sehingga mengakibatkan kesalahan berikutnya.

Untuk kesalahan subjek lain dalam menentukan range, tidak disebabkan oleh proses substitusi x dalam r(x), namun lebih disebabkan karena pemahaman S2 tentang domain dan range yang kurang tepat. Hal ini sesuai dengan pendapat Ulfa, Lubab, dan Arrifadah (2017) menyatakan bahwa penjelasan secara tertulis dari proses pemecahan masalah siswa dalam hal ini mengkomunikasikan ide dan berargumentasi dapat memberikan representasi dan makna yang tepat.

\section{Kemudahan dalam penyusunan kalimat untuk dipahami}

Penyusunan kalimat untuk bisa mudah dipahami orang lain merupakan aspek komunikasi yang sangat ditekankan. Dalam NCTM (2000) disebutkan bahwa salah satu standar komunikasi matematis adalah mengkomunikasikan pemikiran matematis secara 
koheren dan jelas kepada teman, guru dan orang lain. Jika penyusunan kalimat tidak jelas, maka orang lain tidak bisa menangkap ide-ide yang disampaikan. Hal ini berakibat pada kesalahan penilaian orang lain terhadap penyampaian ide-ide tersebut, sehingga komunikasi menjadi tidak lancar.

Berdasarkan paparan data dan wawancara diketahui bahwa subjek pertama dalam menyusun jawaban sering melakukan kesalahan, ketidaklogisan, serta lompatan, sehingga kalimat yang ditulis tidak mudah dipahami. Salah satu kalimat yang tidak mudah dipahami adalah pada saat pengisian tabel, subjek menuliskan $\mathrm{f}(\mathrm{x})$ padahal seharusnya $\mathrm{r}(\mathrm{x})$ dan pengisian nilai fungsinya tidak sesuai dengan rumus fungsi $r(x)$. Untuk subjek subjek yang lain, kalimat tidak tepat pada saat menuliskan range, karena menggabungkan antara simbol operasi pada himpunan ( ) dengan simbol operasi pada pernyataan $(\Lambda)$. Kesalahan penulisan ini terjadi karena menganggap sama antara dua simbol yang berbeda tersebut. Kalimat matematika tersebut bisa mengakibatkan orang lain atau komunitas matematika bingung dalam menangkap ide yang disampaikan. Oleh karena itu, agar penulisan matematika bisa dikenali dengan benar maka bukti ataupun tulisan yang disampaikan harus bisa diterima oleh komunitas matematika. Hal inisesuai dengan pendapat Ariani (2017) yang menyatakan bahwa kemampuan komunikasi matematika adalah kemampuan dalam menyampaikan gagasan/ide matematika, baik secara lisan maupun tulisan serta kemampuan memahami dan menerima gagasan/ide matematika orang lain secara cermat, analisis, kritis, dan evaluatif untuk mempertajam pemahaman.

\section{SIMPULAN DAN SARAN}

Kemampuan metakognitif dan komunikasi matematis dalam memecahkan masalah matematika mahasiswa semester tiga prodi S-1 Pendidikan Matematika FTK UINSA Surabaya pada Matakuliah Teori Bilangan kurang memuaskan karena dalam pemecahan masalah hanya sebagian memahami konsep dan prinsip, sebagian menggunakan istilah dan notasi matematika, dan sebagian besar perhitungan salah karena penggunaan algoritma tidak lengkap dan tidak tepat. Selain itu, komunikasi matematis dalam memecahkan masalah matematika kurang tepat dalam menuliskan jawaban dengan simbol matematika, kurang urut atau kurang logis dalam mengungkapkan ide matematis, sudah menuliskan jawaban yang mengarah sesuai pertanyaan dan kurang memberikan jawaban dengan benar dalam menyusun jawaban sering melakukan kesalahan, ketidaklogisan, serta lompatan, sehingga kalimat yang ditulis tidak mudah dipahami. 
Berdasarkan hasil penelitian bahwa kajian penelitian ini masih terbatas pada kemampuan komunikasi matematis dalam pemecahan masalah matematika pada matakuliah teori bilangan. Sehingga perlu dikaji lebih dalam mengenai kemampuan komunikasi matematis namun tinjauan dari latar belakang mahasiswa yang berbeda.

\section{DAFTAR RUJUKAN}

Anderson, O. W. \& Krathwohl. (2001), A Taxonomy For Learning, Teaching, and Assessing (A Revision of Bloom's Taxonomy of Educational Objectives). New York: Addision Wesley Longman, Inc,.

Ariani, D. N. (2017). Strategi Peningkatan Kemampuan Komunikasi Matematis Siswa SD/MI. Muallimuna Jurnal Madrasah Ibtidaiyah, 3(1), 96-107. DOI: http://dx.doi.org/10.31602/muallimuna.v3i1.958

Huggins, B., \& Maiste T. (1999). Communication in Mathematics. Master's Action Research Project, St. Xavier University \& IRI/Skylight.

Hulukati. (2005). Mengembangkan Kemampuan Komunikasi dan Pemecahan Masalah Matematika Siswa SMP Melalui Model Pembelajaran Generatif. Disertasi Bandung: Universitas Pendidikan, Tersedia pada http://pagesyourfavorite.com/ppsupi/abstrakmat.

Livingstone, J. A. (1997). Metacognition: An Overview. Tersedia pada: http: //www.gse.buffalo.edu/fas/shuell/CEP564/Metacog.html.)

Mahmudi, A. (2006). Pengembangan Kemampuan Komunikasi Matematika Siswa Melalui Pembelajaran Matematika. Dipresentasikan dalam Seminar Nasional Matematika dan Pendidikan Matematika dengan tema "Trend Penelitian dan Pembelajaran Matematika di Era ICT", 176-177.

NCTM. (2000). Principles and Standarts for School Mathematics. Reston, VA: The National Counsil of Teachers of mathematics, Inc. Principles and Standards for School Mathematics, Virginia: Reston.

Ningsih, P. R. (2012). Penerapan metode realistic mathematics education (RME) pada pokok bahasan perbandingan senilai dan berbalik nilai di Kelas VIIE SMP IPIEMS. Skripsi Tidak Dipublikasikan. Surabaya: Gamatika.

Nur, M. (2000). Strategi-Strategi Belajar. Surabaya: Pusat Studi Matematika dan IPA Sekolah.

Rofiqoh, Z. (2015). Analisis Kemampuan Pemecahan Masalah Matematika Siswa Kelas X Dalam Pembelajaran Discovery Learning Berdasarkan Gaya Belajar Siswa. Skripsi Tidak Dipublikasikan. Semarang: Universitas Negeri Semarang.

Polya, G. (1973). How to Solve It ( $2^{\text {nd }}$ Eds.). New Jersey: Princeton University Press. 
Pugalee, D. A. (2001). Using Communication To Develop Student's Literacy. Journal Research of Mathematics Education, 6(5), 296-299.

Sutini. (2017). Proses Berpikir Kritis Siswa dalam Memecahkan Masalah Matematis di SMP Negeri Gresik. Disertasi Tidak Dipublikasikan. Malang: Universitas Negeri Malang.

Ulfa, M., Lubab, A., \& Arrifadah, Y. (2017). Melatih Literasi Matematis Siswa dengan Metode Naive Geometry. Jurnal Review Pembelajaran Matematika, 2(1), 81-92. DOI: https://doi.org/10.15642/jrpm.2017.2.1.81-92. 